Original Report

\title{
Effect of duration of heat exposure on upland weed seed viability
}

\author{
Tomoko Nishida*, Shunji Kurokawa**, Shohei Shibata* and Norihisa Kitahara*
}

\begin{abstract}
A study was conducted to determine the length of exposure to heat necessary to kill water-imbibing weed seeds at 55 and $60^{\circ} \mathrm{C}$. The examination covered ten upland weed species: Solanum carolinense L., S.
\end{abstract} americanum Mill., Abutilon theophrasti Medic., Phytolacca americana L., Amaranthus spinosus L., A. patulus Bertoloni, Persicaria lapathifolia (L.) S. F. Gray, Panicum dichotomiflorum Michx, Echinochloa crus-galli (L.) Beauv. var. crus-galli and Digitaria ciliaris (Retz.) Koeler. All seeds of each species were killed by exposure to heat at $55^{\circ} \mathrm{C}$ for $72 \mathrm{hr}$ and at $60^{\circ} \mathrm{C}$ for $24 \mathrm{hr}$ except for those of Abutilon theophrasti (dormant seed rate $80 \%$ ) which were killed by exposure for 120 and $30 \mathrm{hr}$ at the respective temeratures.

These weed species fell into four groups, categorized by a combination of short-duration heat-tolerance (SDHT) and long-duration heat-tolerance (LDHT). SDHT was determined by the viability of weed seeds when treated at $60^{\circ} \mathrm{C}$ for $3 \mathrm{hr}$, with low and high subcategories of tolerance. LDHT was detemined by the duration required to kill all the seeds at $1 \%$ level of significance when treated at $60^{\circ} \mathrm{C}$, into three subcategories (low, medium and high tolerance). Persicaria lapathifolia, E. crus-galli, and D. ciliaris were low for both SDHT and LDHT (Group I), and Amaranthus spinosus and Panicum dichotomiflorum were low-SDHT and medium

\footnotetext{
* Department of Grassland Management, National Grassland Research Institute, Nishinasuno, Nasu, Tochigi, 329-2793 Japan

** Department of Forage Production and Utilization, NGRI

(Accepted September 9, 1998)
}

- LDHT (Group II). Solanum species, Phytolacca americana, and Amaranthus patulus were high-SDHT and mediumLDHT (Group III), while Abutilon theophrasti was low-SDHT and high-LDHT (Group IV). The viability of seeds at short-duration heat treatment for Group I, II and IV was low, but the durations required to kill all seeds were different among the groups. Group III consisted of species for which the viability of seeds at short-duration heat treatment was high, and the fatal duration was medium.

For Abutilon teophrasti which required the longest duration of heat exposure to kill all seeds at each temperature, $95 \%$ confidence intervals of $\mathrm{LD}_{90}$ values were calculated using the probit method, and were 42 to 58 and 10 to $17 \mathrm{hr}$ at 55 and $60^{\circ} \mathrm{C}$, respectively.

Key words: weed seed, heat death, heat exposure duration, heat tolerance, Abutilon theophrasti

\section{Introduction}

Imported concentrate is considered a major invasion route of the alien weed seeds that afflict forage-crop fields and pastures in Japan ${ }^{17)}$. Since some weed seeds retain their viability after passing through the bovine digestive tract, ${ }^{4,9,18)}$ weed seeds in animal excreta must be killed in the process of composting before manure is spread over fields. Effective control of weed seeds in the composting process requires adequate temperatures ${ }^{13,19)}$. We showed that weed seeds were unable to germinate after exposure in compost to temperatures above approximate- 
ly $60^{\circ} \mathrm{C}^{13)}$, and that almost all of the tested seeds in plastic petri dishes were dead when they were exposed to the temperature of $55^{\circ} \mathrm{C}$ for 5 days after imbibing water at $30^{\circ} \mathrm{C}$ for 24 $\mathrm{hr}^{12}$. However, the relationship between the rate of heat death of weed seeds and shorter terms of heat exposure remains unclear. Additional experiments are required to reveal this relationship because the process of composting cannot always provide the conditions necessary to kill seeds, especially during the wintertime ${ }^{11}$.

The heat tolerance of seeds varies with their water uptake, and water-imbibing seeds have lower heat tolerance than air-dried seeds ${ }^{6,15,19)}$. The water content of manure is usually about 65 to $70 \%$ when composting begins $^{1)}$, and it is assumed that seeds embedded in manure absorb water from manure before being exposed to fermentative heat. In this study, we examined the death rate of weed seeds which absorbed water at $15^{\circ} \mathrm{C}$ for $24 \mathrm{hr}$ before heat treatment. The water uptake of seeds in manure, befor being exposed to heat, varies depending on several factors such as the water content and temperature of manure, the lengh of time that the seeds are embedded in the manure and the degree of their dormancy, etc.

Although it is reported that the temperature of $45^{\circ} \mathrm{C}$ adversely affected the germination of Solanum nigrum ${ }^{5)}$ and Abutilon theophrasti seeds ${ }^{6}$, in our previous study some seeds of the tested weed species retained their viability after exposure to a $45^{\circ} \mathrm{C}$ temperature over the course of an entire week ${ }^{12)}$. The maximum temperature in manure tends to rise above $45^{\circ} \mathrm{C}$ when the manure temperature remains above $45^{\circ} \mathrm{C}$ for more than one week $^{3,11,19}$. Weed seeds lose germinating abilities following exposure in compost to temperatures above approximately $60^{\circ} \mathrm{C}^{13)}$. Therefore, we conducted this study to exam- ine the effect of duration of heat exposure at 55 and $60^{\circ} \mathrm{C}$, respectively, on the viability of weed seeds.

\section{Materials and Methods}

The experiments were conducted from March to September in 1997.

Weed seeds. We selected ten weed species that commonly occur in forage-crop fields and pastures in Japan: Solanum carolinense L., S. americanum Mill., Abutilon theophrasti Medic., Phytolacca americana L., Amaranthus spinosus L., A. patulus Bertoloni, Persicaria lapathifolia (L.) S. F. Gray, Panicum dichotomiflorum Michx, Echinochloa crus-galli (L.) Beauv. var. crus-galli and Digitaria ciliaris (Retz.) Koeler. Among these, Persicaria lapathifolia, E. crus-galli and D. ciliar$i$ s are native to Japan; the other weeds were introduced from overseas after 1854 when Japan was opened to foreign intercourse. The seeds for the experiment were collected in Tochigi Prefecture during 1994 and 1996, air -dried and stored at room temperature.

Water uptake. Samples consisted of 150 airdried seeds for Amaranthus species, 90 for $S$. americanum, Panicum dichotomiflorum and D. ciliaris, 60 for E. crus-galli and 30 for others. A sample of each species was weighed, placed on filter paper and absorbent cotton in a glass petri dish $($ d. $6-\mathrm{cm})$, and supplied with $20 \mathrm{ml}$ of deionized water. The seeds were incubated at $15^{\circ} \mathrm{C}$ for $24 \mathrm{hr}$ in darkness and re-weighed for water uptake after removal of external moisture by blotting.

Heat treatment. Thirty seeds of each species which absorbed water under the conditions given above were exposed to a temperature of $55^{\circ} \mathrm{C}$ for a period of $24 \mathrm{hr}$, and to a temperature of $60^{\circ} \mathrm{C}$ for $3 \mathrm{hr}$. After exposure to heat stress, they were incubated for a germination test at alternate temperature and light condi- 
tions of $30^{\circ} \mathrm{C} / 12 \mathrm{hr}$ light and $20^{\circ} \mathrm{C} / 12 \mathrm{hr}$ dark. A germination count was made over a 20 -day period. Sound seeds that did not germinate were subsequently tested for viability by tetrazolium $(\mathrm{Tz})$ test $^{2}$. Seeds that germinated or were stained with $\mathrm{Tz}$ were classified as 'viable seeds'. Those that collapsed when they were pinched with a pair of tweezers or were not stained were classified as 'dead seeds'. For the species of which seeds remained viable after this heat exposure, the duration of exposure at each temperature was extended until all seeds were killed. The germination and viability rates of the seeds were recorded at each duration and temperature.

At the beginning of the experiment, untreated seeds were also tested for germination and viability, as were the treated seeds. Dormancy rates were calculated by subtracting the germination rate from the viable seed rate for untreated seeds. As the seed dormancy rate for Abutilon theophrasti was quite high at the beginning of the experiment, we re-examined this rate with untreated seeds at the end to determine if there were any changes in the rate of dormancy over the duration of the experiment using the germination test.

Statistical analyses. In all cases, the experimental design was Completely Randomized Design with three replications. Germination and viability rates were arcsin transformed prior to analyses of variance ${ }^{16}$. Means of germination and viability within each species were tested between treatments by the $1 . \mathrm{s}$. $\mathrm{d}$. method $^{16)}$, and viability means for the $3 \mathrm{hr}$ treatment at $60^{\circ} \mathrm{C}$ were tested between species using the same method.

For $A$. theophrasti, which required the longest period of heat exposure to kill all seeds at each temperature, $95 \%$ confidence intervals of $\mathrm{LD}_{90}$ values were calculated using the probit method ${ }^{16)}$. The probit method assumes a normal distribution for the dose that induces response. The response rate at each dose is converted into 'surveyed probit' using a normal distribution table and a transformation equation. 'Estimated probits' are calculated from surveyed probits, and then modified in order to obtain 'practical probits'. A weighted regression equation between the doses and practical probits is calculated. Then $95 \%$ confidence interval of $\mathrm{LD}_{90}$ value is calculated using the equation.

\section{Results and Discussion}

Water uptake rate. Following water absorption, the water uptake of the various species of seeds ranged from 6 to $60 \%$ (Table 1 ). Water uptake was lowest for Phytolacca americana and highest for E. crus-galli.

Dormancy rate. The highest dormancy rate of $80 \%$ was recorded for $A$. theophrasti seeds. Dormancy rates for $E$. crus-galli and $D$. ciliaris seeds were 34 and $14 \%$, respectively, and those for seeds of other species were very low (Table 1).

The germination rate for $A$. theophrasti seeds at the beginning and at the end of the experiment was 13 and $11 \%$, respectively. The dormancy rate for $A$. theophrasti appeared to remain unchanged during the experiment.

Although the dormancy rates for $S$. carolinense, Persicaria lapathifolia and Panicum dichotomiflorum were quite low in this experiment, it has been reported that their seeds do demonstrate dormancy ${ }^{8,9,20)}$. It appears that the dormancy dissipated during the storage period of one to two years before the beginning of the present study.

\section{Heat treatment.}

1) Effect of heat treatment. Seeds of all the species except for $A$. theophrasti were killed by exposure to temperatures of 55 and $60^{\circ} \mathrm{C}$ 
Table 1. Rates of water uptake and dormancy of untreated seeds

\begin{tabular}{llr}
\hline \multicolumn{1}{c}{ species } & $\begin{array}{c}\text { water } \\
\text { uptake }^{\mathrm{a})}\end{array}$ & $\begin{array}{c}\text { Dormancy } \\
\text { rate }^{\mathrm{b})}\end{array}$ \\
\cline { 2 - 3 } Solanum carolinense & $44(2)^{\mathrm{c})}$ & $2(2)$ \\
S. americanum & $37(2)$ & $0(0)$ \\
Abutilon theophrasti & $12(5)$ & $80(6)$ \\
Phytolacca americana & $6(1)$ & $2(4)$ \\
Amaranthus spinosus & $33(3)$ & $0(0)$ \\
A. patulus & $29(1)$ & $1(2)$ \\
Persicaria lapathifolia & $24(3)$ & $0(0)$ \\
Panicum dichotomiflorum & $20(2)$ & $6(2)$ \\
Echinochloa crus-galli & $60(3)$ & $34(13)$ \\
Digitaria ciliaris & $54(3)$ & $14(4)$ \\
\hline
\end{tabular}

Note:

a) Weed seeds were supplied $20 \mathrm{ml}$ of deionized water, and the water uptake was measured after incubation at $15^{\circ} \mathrm{C}$ for $24 \mathrm{hr}$.

Water uptake $(\%)=\frac{\text { WISW }- \text { ADSW }}{\mathrm{ADSW}} \times 100$

WISW: water-imbibing seed weight

ADSW: air-dried seed weight

b) The dormancy rate was calculated by subtracting the germination rate from the viable seed rate after absorption of water and incubation for 20 days at $20 / 30^{\circ} \mathrm{C}$

Dormancy rate $(\%)=$ Viability $(\%)$ - Germination rate(\%)

c) Values in parentheses represent s. d.

for the respective durations of 72 and $24 \mathrm{hr}$ (Table 2). The germination rate for $A$. theophrasti was $0 \%$ following $24 \mathrm{hr}$ of heat treatment at both 55 and $60^{\circ} \mathrm{C}$ but the seeds remained viable. The time required to kill all A. theophrasti seeds at temperatures of 55 and $60^{\circ} \mathrm{C}$ was 120 and $30 \mathrm{hr}$, respectively.

According to the result of analyses of variance, there was no significant difference between untreated seeds and those undergoing the briefest heat exposure for $A$. theophrasti germination rate at $60^{\circ} \mathrm{C}$, or for $S$. americanum viability at either 55 and $60^{\circ} \mathrm{C}$ (Table 2). Except for these cases, even the briefest heat treatment, $24 \mathrm{hr}$ at $55^{\circ} \mathrm{C}$ and $3 \mathrm{hr}$ at $60^{\circ} \mathrm{C}$, significantly reduced the germination rate and viability of all species compared to untreated seeds. The lenght of exposure required to kill all $A$. theophrasti seeds at $1 \%$ level of significance was 96 and $30 \mathrm{hr}$ at 55 and $60^{\circ} \mathrm{C}$, respectively, the longest among the species studied. The briefest fatal exposures were for Persicaria lapathifolia, E. crus-galli, and $D$. ciliaris, with minimum durations of 24 $\mathrm{hr}$ at $55^{\circ} \mathrm{C}$ and $3 \mathrm{hr}$ at $60^{\circ} \mathrm{C}$.

In a comparison of brief heat-exposure tolerance among the species based on the viability in the $3-\mathrm{hr}$ treatment at $60^{\circ} \mathrm{C}, S$. carolinense, S. americanum, Phytolacca americana, and $A$. patulus with high viability showed high tolerance. The lowest viability was observed for Persicaria lapathifolia, E. crus-galli, and D. ciliaris.

2) Grouping by a combination of short-and long-duration heat-tolerance. The tested weed species were grouped by a combination of short-duration heat-tolerance (SDHT) and long-duration heat-tolerance (LDHT). SDHT was determined by viability of the seeds when treated for $3 \mathrm{hr}$ at $60^{\circ} \mathrm{C}$. Species with viabilities below and above the $50 \%$ mark were subcategorized as low-SDHT and high-SDHT, respectively. LDHT sorted the species into three groups, depending on the duration required to achieve $100 \%$ death rate of seeds at $1 \%$ level of significance when the seeds were treated at $60^{\circ} \mathrm{C}$. The subcategories were described as low ( $3 \mathrm{hr}$ ), medium ( $6 \mathrm{hr}$ ), or high tolerance $(30 \mathrm{hr})$. The ten species fell into four groups (Table 3). Persicaria lapathifolia, E. crus-galli, and D. ciliaris were low for both SDHT and LDHT (Group I ), and A. spinosus and Panicum dichotomiflorum were low-SDHT and medium-LDHT (Group II). Solanum species, Phytolacca americana, and $A$. patulus were high-SDHT and medium -LDHT (Group III), while A. theophrasti was 
Table 2. Rates of germination and viability of weed seeds exposed to heat for different periods at 55 and $60^{\circ} \mathrm{C}$

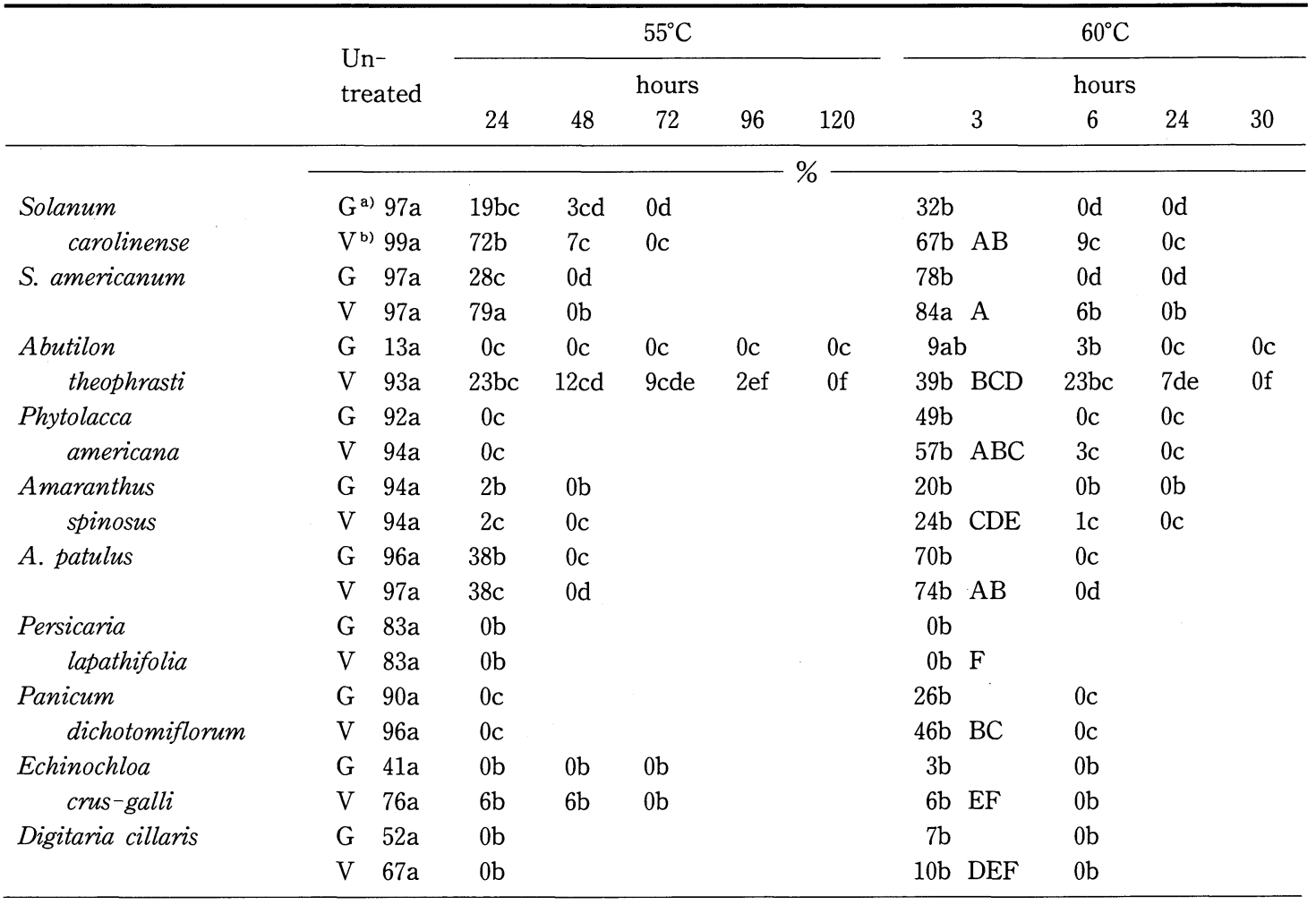

Note:

Values in the same row (small letters) or column (capital letters) followed by the same letter are not different at $1 \%$ level of significance.

a)germination rate ${ }^{b)}$ viability

low-SDHT and high-LDHT (Group IV). The viability of seeds at short-duration heat treatment for Group I, II and IV is low, but the durations required to kill all seeds differed among the groups. Group III consists of species for which the viability of seeds at short-duration heat treatment is high, and the fatal duration is intermediate.

It has been reported that non-dormant seeds of $A$. theophrasti are heat-sensitive ${ }^{12)}$, while dormant ones are heat-tolerant ${ }^{7)}$. This may explain $A$. theophrasti's grouping into Group IV.

Dormancy rates for $S$. carolinense and $S$. americanum classified as high-SDHT were quite low for untreated seeds, but dormant seeds were observed for these species after 24 -and 6 - $\mathrm{hr}$ treatments at 55 and $60^{\circ} \mathrm{C}$, respectively (Tables 1 and 2). Dormancy is thought to increase heat tolerance, but $D$. ciliaris and E. crus-galli, of which untreated seeds were dormant, rated low for both SDHT and LDHT (Tables 1 and 3).

For non-dormant $A$. theophrasti seeds, it has been reported that water uptake is negatively correlated with heat tolerance ${ }^{6}$. We found in this study that Phytolacca americana, with the lowest water uptake among the tested species, showed high-SDHT, while $D$. ciliaris and E. crus-galli, with high water 
Table 3. Heat tolerance of tested weeds

\begin{tabular}{|c|c|c|c|}
\hline & & \multicolumn{2}{|c|}{ Short-duration heat-tolerance ${ }^{a)}$} \\
\hline & & Low & High \\
\hline \multirow{3}{*}{$\begin{array}{l}\text { Long-duration } \\
\text { heat-tolerance }^{\text {b) }}\end{array}$} & Low & $\begin{array}{l}\quad \text { Group I } \\
\text { Persicaria lapathifolia } \\
\text { Echinochloa crus-galli } \\
\text { Digitaria ciliaris }\end{array}$ & \\
\hline & Medium & $\begin{array}{l}\text { Group II } \\
\text { Amaranthus spinosus } \\
\text { Panicum dichotomiflorum }\end{array}$ & $\begin{array}{l}\text { Group III } \\
\text { Solanum carolinense } \\
\text { S. americanum } \\
\text { Phytolacca americana } \\
\text { Amaranthus patulus }\end{array}$ \\
\hline & High & $\begin{array}{c}\text { Group IV } \\
\text { Abutilon theophrasti }\end{array}$ & \\
\hline
\end{tabular}

Note:

a) Short-duration heat-tolerance (SDHT) was detemined by the viability of seeds when treated at $60^{\circ} \mathrm{C}$ for 3 hr, with low (below 50\%) and high (above 50\%).

b) Long-duration heat-tolerance (LDHT) was detemined by the duration required to kill the seeds at $100 \%$ rate at $1 \%$ level of significance when treated at $60^{\circ} \mathrm{C}$, with low $(3 \mathrm{hr})$, medium $(6 \mathrm{hr})$ and high $(30 \mathrm{hr})$.

uptake, showed low heat tolerance for both long and short periods (Tables 1 and 3). On the other hand, we observed that $S$. carolinense and S. americanum demonstrated highSDHT, despite relatively high water uptake, while $A$. patulus and $A$. spinosus demonstrated different heat tolerance, despite similar water uptake levels.

The dormancy and water uptake of seeds are correlated with the heat tolerance of a species, but it is apparent that other factors also need to be considered to explain the difference of heat tolerance between species. For example, seed coat structure, seed reserves, and the period over which an embryo is sensitive to the-temperature after the seed has started absorbing water may influence heat tolerance. Further studies are required.

\section{3) Fatal exposure duration for} A. theophrasti. Because the duration of exposure to heat needed to kill all the seeds was longest for $A$. theophrasti, the viability of the seeds can be considered as an index of fatal exposure for the tested species. In order to quantify the relationship between death rate and duration for which $A$. theophrasti seeds were exposed, a detailed analysis was carried out. We calculated 95\% confidence intervals of $\mathrm{LD}_{90}$ values using the probit method and obtained values of 1.62 to 1.76 or 42 to $58 \mathrm{hr}$ at $55^{\circ} \mathrm{C}$ and 1.01 to 1.24 or 10 to 17 hr at $60^{\circ} \mathrm{C}$ (Fig. 1).

4) Conclusion. Reports indicate the process of composting can provide temperatures above $55^{\circ} \mathrm{C}$ for 96 to $144 \mathrm{hr}^{3,11,19)}$ and temperatures above $60^{\circ} \mathrm{C}$ for 72 to $120 \mathrm{hr}$. Thus, given normal composting conditions, both temperature and length of heat exposure are sufficient to kill all weed seeds, including dormant $A$. theophrasti ones. The study design does not rule out the possibility that other factors, including ammonia ${ }^{10,14)}$ and microorganisms, may have significant effects on the viability of weed seed in manure.

\section{Acknowledgments}

We would like to express our appreciation 


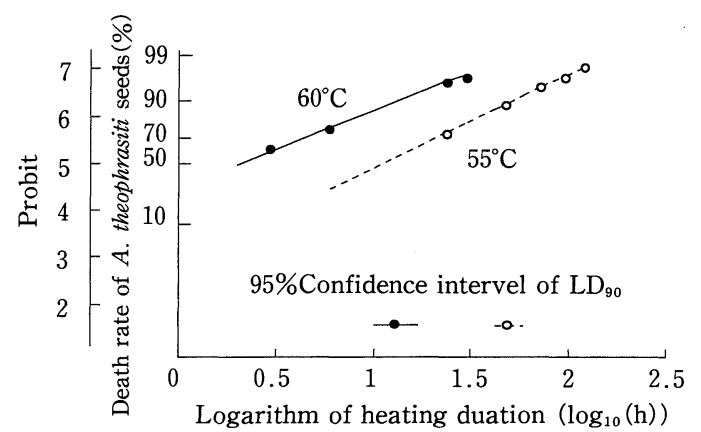

Fig.1. Relationship between logarithms of heating duration and death rate of Abutilon theophrasti seeds

Circles show 'estimated probits' at each temperature $\left(\bigcirc 55^{\circ} \mathrm{C}, 60^{\circ} \mathrm{C}\right)$. Weighted regression equations between logarithms of heating duration and 'practical probits' that were modified 'estimated probits', were calculated. $55^{\circ} \mathrm{C} \mathrm{y}=2.884+2.009 \mathrm{x} \chi^{2}=4.794<\chi^{2}{ }_{(3,0.05)}$ $60^{\circ} \mathrm{C} \mathrm{y}=4.469+1.648 \mathrm{x} \chi^{2}=4.115<\chi^{2}{ }_{(2,0.05)}$ According to $\chi^{2}$ of the equations, their linearity was undeniable.

to Dr. N. Shimizu, Dr. M. Nashiki and Dr. I. Ezenwa, all of NGRI, Nishinasuno, for advice and comments on the manuscript. We also sincerely thank Ms. Y. Yoshida for her assistance in these experiments.

\section{References}

1 ) Anonymous 1987. Manual of composting facility design. Chuochikusankai, Tokyo, pp.94-123 [In Japanese].

2 ) Anonymous 1991. International Rules for Seed Testing. National Center for Seeds and Seedlings, Ibaraki, pp.122-124 [In Japanese].

3 ) Arikawa K., H. Matsuzaki, F. Nonaka and M. Sugimoto 1973. Quick composting of animal waste. Agric. and Hort. 7, 935-938 [In Japanese].

4) Atkeson, F. W., H. W. Hulbert and T. R. Warren 1934. Effect of bovine digestion and of manure storage on the viability of weed seeds. J. Am. Soc. Agron. 26, 390-397.

5 ) Givelberg, A. and M. Horowitz 1984. Germination behaviour of Solanum nigrum seeds. J. Exp. Bot. 35, 588-598.
6) Horowitz, M. and R. B. Taylorson 1983. Effect of high temperatures on imbibition, germination, and thermal death of velvetleaf (Abutilon theophrasti) seeds. Can. J. Bot. 61, 2269-2276.

7 ) Horowitz, M. and R. B. Taylorson 1984. Hardseededness and germinability of velvetleaf (Abutilon theophrasti) as affected by temperature and moisture. Weed Sci. 32, 111-115.

8 ) Ilnicki, R. D., T. F. Tisdell, S. N. Fertig and A. H. Furrer, Jr. 1962. Life history studies as related to weed control in the Northeast 3 Horse nettle. Univ. R. I. Agric. Exp. Sta. Bull. 368

9) Itoh, M. 1993. Introduction to Weed Science. Yokendo Ltd., Tokyo, pp.51, 99 [In Japanese].

10) Kuroda, K., T. Osada, N. Yonaga, A. Kanematu, T. Nitta, S. Mouri and T. Kojima 1996. Emissions of malodorous compounds and greenhouse gases from composting swine feces. Bioresource Tech. 56, 265-271.

11) Nishida, T., N. Shimizu, N. Harashima and S. Uozumi 1994. Sources of alien weed seed invading pastures and forage crop fields, and countermeasures. Self-sufficient Forage 20, 15-21 [In Japanese].

12) Nishida, T., T. Onoue and N. Harashima 1996. Effect of temperature and heating time on weed seed viability. Weed Res., Japan 41 (Suppl.), 3435 [In Japanese].

13) Nishida, T., N. Shimizu, M. Ishida, T. Onoue and N. Harashima 1998. Effect of cattle digestion and of composting heat on weed seeds. JARQ 32, 5560.

14) Noguchi, K. and K. Nakatani 1992. Method for killing of upland weed seeds. (1) Reference to seed-cide. Weed Res., Japan 37 (Suppl.), 194-195 [In Japanese].

15) Noguchi. K. and T. Egawa 1994. Method for killing of upland weed seeds. (3) Effect of heat. Weed Res., Japan 39(Suppl.), 250-251 [In Japanese].

16) Okuno, T. (ed.) 1978. Applied Statistics Handbook. Yokendo, Tokyo, pp.108, 208 and 700-705 [In Japanese].

17) Shimizu, N., S. Kurokawa and S. Uozumi 1995. Establishment and diffusion mechanism of alien weeds invading grassland and forage crop fields (II). Weed Res., Japan 40(Suppl.), 178-179 [In Japanese]. 
18) Takabayashi, M., R. Abe and T. Kubota 1975. Studies on the dissemination of weed seeds by livestock. 1. Viability of weed seeds passed through digestive tract of dairy cow. Weed Res., Japan 19, 36-40 [In Japanese with English summary].

19) Takabayashi, M., T. Kubota and R. Abe 1978.
Dissemination of weed seeds by livestock. 2 . Methods to kill weed seeds. J. Cent. Agric. Exp. Stn. 27, 69-91 [In Japanese with English summary].

20) Takano, N., Y. Yoshiyama and H. Kawanabe (ed.) 1989. Forage and Grassland Handbook. Yokendo, Ltd. Tokyo. pp.419 [In Japanese].

\section{畑雑草種子の生存に及ぼす加熱時間の影響}

西田智子* ・黒川俊二** ・柴田昇平* ・ 北原徳久*

\section{摘要}

現在, 草地・飼料畑で大きな問題になっている外 来雑草の侵入経路の一つとして, 雑草種子の混入し た輸入濃厚飼料が家畜に採食され, 糞が堆厩肥とし て圑場に還元される過程で, 生存したままの種子が 畕場に散布されることがあげられている。家畜の消 化作用ではすべての種子を死滅させることは不可能 なため, 堆肥製造過程で雑草種子を死滅させること が, 外来雑草を蔓延させないために必要である。堆 厩肥中の雑草種子は, 堆肥の最高温度が約 $60^{\circ} \mathrm{C}$ 以上 になれば, 発芽力を失うことが明らかにされている が, 温度の持続時間と種子の死滅率の詳細は不明で

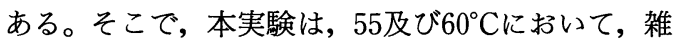
草種子がそれらの温度にさらされる時間と死滅率と の関係について調査した。

10 種類の畑雑草種子 (ワルナスビ, アメリカイヌ ホオズキ,イチビ, ヨウシュヤマゴボウ, ハリビュ, ホソアオゲイトウ, オオイヌタデ，オオクサキビ, イヌビエ及びメヒシバ）を， $15^{\circ} \mathrm{C}$ 暗条件で 24 時間吸 水させた。種子の吸水率は 6 〜 $60 \%$ 範囲であった

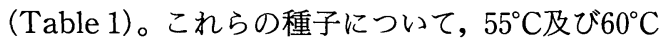
の処理で, 死滅率が $100 \%$ とる時間を調査した。イ チビを除く 9 種類の雑草は, $55^{\circ} \mathrm{C} て ゙ 72$ 時間, $60^{\circ} \mathrm{C}$ で 24時間処理すれば全ての種子が死滅した。イチビ(休 眠率 $80 \%$ )については， $55^{\circ} \mathrm{Cでは} 120$ 時間， $60^{\circ} \mathrm{Cでは}$ 30時間の加熱が必要であった（Table 2)。

調査した 10 種類の雑草の加熱耐性を, 短時間の熱 処理に対する耐性 (SDHT) と，長時間の熱処理に
対する耐性（LDHT）とを組み合わせて分類した。 $\mathrm{SDHT}$ は $60^{\circ} \mathrm{C} 3$ 時間処理での生存率により, $50 \%$ を 境に低及び高耐性の 2 群に分けた。LDHTは, $60^{\circ} \mathrm{C}$ 処理において $1 \%$ の有意水準で生存率 $0 \%$ と差が無 くなるまでにかかった処理時間により，低，中，高 耐性の 3 群に分類した。その結果, SDHT, LDHT ともに低いオオイヌタデ,メヒシバ及びイヌビエ(第 1 群), SDHT が低く LDHT が中位のハリビュ及び オオクサキビ(第 2 群), SDHT が高く LDHT が中 位のワルナスビ, アメリカイヌホオズキ, ヨウシュ ヤマゴボウ及びホソアオゲイトウ(第 3 群), SDHT が低いが LDHT の高いイチビ (第 4 群)の 4 群に分 かれた (Table 3)。第 1,2 及び 4 群は, 短時間の 熱処理で高い死滅率を示すが, $100 \%$ の種子が死ぬま でにかかる時間はそれぞれ異なるといえる。また， 第 3 群は, 短時間の熱処理では生存率が高いが, 100 \%の種子が死ぬまでにかかる時間はそれほど長くな い群である。

調査した 10 種類の雑草種子を死滅させるための時 間はイチビ種子の死滅を目安として設定すればよい と考えられたので, イチビについて, プロビット法 により $\mathrm{LD}_{90}$ となる時間の $95 \%$ 信頼区間を計算した。 その結果, $55^{\circ} \mathrm{C} て ゙ は 42 〜 58$ 時間, $60^{\circ} \mathrm{C} て ゙ は 10 〜 17$ 時 間となった（Fig. 1)。

本実験の結果と既往の堆厩肥の発酵温度に関する 報告とからみて, 堆厩肥が順調に発酵した場合は, イチビを含むすべての種子が死滅する温度と時間を 確保できるといえる。

キーワード：雑草種子, 熱死, 加熱時間, 熱耐性, イチビ
*草地試験場 草地生産基盤部 飼料基盤管理研究室

**草地試験場 飼料生産利用部 栽培生理研究室 